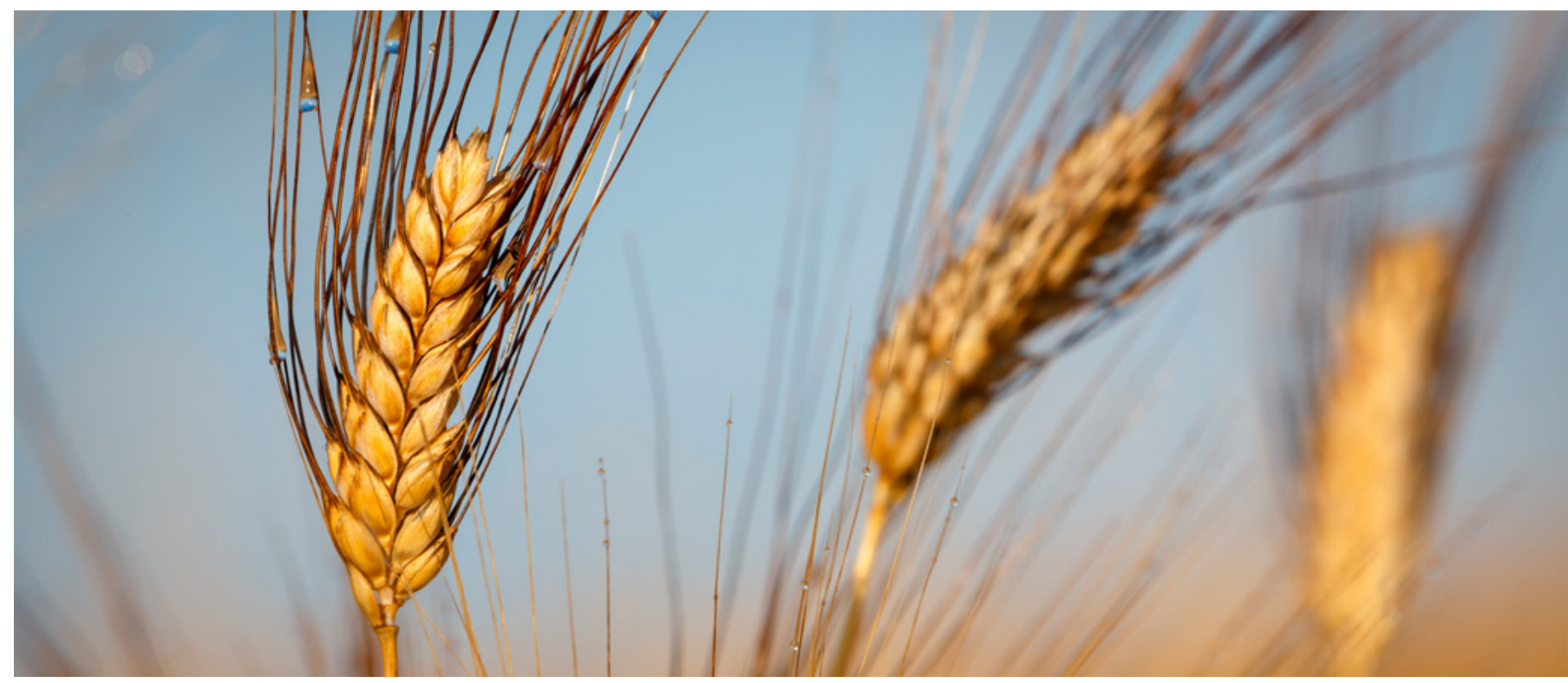

\title{
Integraal sturen op doelen voor duurzame landbouw via KPI's
}

Juni 2021

Deze notitie is bedoeld als achtergrondstuk voor beleidsmakers, betrokkenen bij experimenteergebieden en andere stakeholders die aan de slag zijn met de ontwikkeling van Kritische Prestatie Indicatoren (KPI's) voor duurzame kringlooplandbouw. De notitie biedt een gezamenlijk kader voor deze ontwikkeling. Een gezamenlijk kader is belangrijk doordat aan de vergader- en keukentafels verschillende beelden en verwachtingen ontstaan over de ontwikkeling van een KPI-systematiek voor kringlooplandbouw, wat de samenwerking in de weg kan staan. Deze notitie geeft daarom richting aan de verdere ontwikkeling en toepassing van een KPI-systematiek voor kringlooplandbouw.

1 Waarom een KPI-systematiek Kringlooplandbouw? 1.1 De landbouw speelt een belangrijke rol bij u rgente maatschappelijke opgaven

1.2 Integrale sturing is cruciaal voor het realiseren van doelen

1.3 KPI als bruikbaar instrument voor integrale sturing op het boerenerf
2 Afbakening KPI-systematiek 2.1 Conceptueel kader 2.2 Systeemeisen

\section{Mogelijke toepassing en vervolgstappen} 3.1 Verwachte toepassing van de KPI-systematiek 3.2 Toetsing van eerste kernset in gebiedspilots 3.3 Leer- en ontwikkelvragen 


\section{Leeswijzer}

In deze notitie wordt in het eerste hoofdstuk eerst de behoefte toegelicht: KPI's voor kringlooplandbouw zijn geen doel op zich maar een instrument dat boeren integraal richting geeft in hoe zij kunnen bijdragen aan het behalen van doelen op het gebied van klimaat, bodem, biodiversiteit. In het tweede deel wordt vervolgens verder uitgewerkt en afgebakend wat de beoogde werking van een KPI-systematiek is, inclusief een gedetailleerde uitwerking van systeemeisen. In het derde deel wordt ingegaan op de mogelijkheden voor toepassing en vervolgstappen in het project.

\section{Waarom een KPI-systematiek Kringlooplandbouw?}

\subsection{De landbouw speelt een belangrijke rol bij urgente maatschappelijke opgaven}

De maatschappelijke opgaven op het gebied van achteruitgang van de biodiversiteit, tegengaan van en omgaan met klimaatverandering, hergebruik van grondstoffen, landschapskwaliteit, lucht-, bodem- en waterkwaliteit en dierenwelzijn zijn groot, complex en talrijk. Als bepalende factor in het landelijk gebied heeft de landbouw een sleutelrol in het realiseren van deze opgaven. Hierbij zijn niet alleen individuele boeren aan zet maar zeker ook boerenorganisaties, ketenpartijen, de consument, overheden, natuur- en milieuorganisaties en andere maatschappelijke groeperingen, aangezien de effecten op verschillende ruimtelijke schalen spelen en een individuele boer maar beperkte mogelijkheden heeft om dat alleen te beïnvloeden.

De overheid en andere partijen hebben doelen gesteld voor de maatschappelijke opgaven. Ten aanzien van klimaat, biodiversiteit, lucht- en waterkwaliteit zijn in internationaal verband doelen afgesproken en heeft de landelijke en provinciale overheid verplichtingen op zich genomen (Klimaatakkoord van Parijs, Vogel Habitat Richtlijn, Kader Richtlijn Water). In de visie 'Landbouw, Natuur en Voedsel: waardevol en verbonden. Nederland als koploper in kringlooplandbouw' (LNV 2018) wordt gepleit voor een landbouw waarbij zo min mogelijk afval vrijkomt, de uitstoot van schadelijke stoffen zo klein mogelijk is en grondstoffen en eindproducten met zo min mogelijk verliezen worden benut. Het Deltaplan Biodiversiteitsherstel heeft ingezet op biodiversiteitsherstel ofwel 'bending the curve' (WNF, 2020).

\subsection{Integrale sturing is cruciaal voor het realiseren van doelen}

Het gelijktijdig realiseren van de totale set aan doelen in de huidige praktijk is complex om meerdere redenen:

- Duurzaamheidsmaatregelen in de landbouw worden vaak aangestuurd vanuit afzonderlijke beleidsdossiers. Dit heeft ertoe geleid dat op dossiers zoals bodemkwaliteit, broeikasgassen, waterkwaliteit of ammoniak wel in beeld is welke stappen boeren kunnen zetten, maar dat een goed overzicht ontbreekt over de effecten van deze maatregelen op de andere doelen (neveneffecten), op relaties en afwentelingen tussen doelen onderling en daarmee op de haalbaarheid van doelen in samenhang.

- Vaak zijn doelen ook onvoldoende concreet gemaakt, waardoor het niet mogelijk is inzicht te bieden welke inzet nodig is om doelen te realiseren. Als gevolg hiervan gaan veel initiatieven uit van het verbeteren van het bestaande (bijvoorbeeld efficiëntie), zonder inzicht te geven in wat nodig is om doelen (bijvoorbeeld voor natuur en biodiversiteit) te behalen. 
- Een probleem is dat resultaten van bestaande instrumenten en tools momenteel niet optellen tot landschaps- of ecosysteemniveau, omdat eenduidigheid in meetmethoden ontbreekt (bijvoorbeeld tussen sectoren) en het gebruik van instrumenten versnipperd is.

- Maatregelen zijn niet eenduidig toe te passen omdat effecten afhankelijk zijn van de context van het landbouwbedrijf (denk bijvoorbeeld aan grondsoort, regio, bouwplan, stalsysteem).

- De huidige economische realiteit is dat betere prestaties op duurzaamheid niet altijd worden beloond en dat de afzetmarkt voor boeren competitief is met kleine marges die geen ruimte bieden voor vergaande of dure maatregelen als hier geen directe vergoeding tegenover staat.

- Allerlei maatregelvoorschriften komen samen op het boerenerf, waardoor onoverzichtelijke, ineffectieve en soms ook tegenstrijdige inzet van maatregelen ontstaat: boeren zien door alle (maat)regels de doelen niet meer. De complexiteit en tegenstrijdigheid van bestaande regels wordt door boeren ook als belemmerend ervaren om te experimenteren met nieuwe technieken.

Dit alles maakt dat er zowel vanuit beleid, keten als de sector behoefte is aan een integrale set van doelen waar men aan kan bijdragen: via een systematiek waarin alles bij elkaar komt. Om effectief te werken aan doelrealisatie is het belangrijk om boeren meer handelingsperspectief te bieden door a) te sturen op concrete doelen gekoppeld aan een moment waarop die gerealiseerd moeten worden, b) een integrale benadering van deze doelen en c) het inzichtelijk, overzichtelijk en meetbaar maken van prestaties zodat bijdragen van boeren Om effectief te werken aan doelrealisatie is het belangrijk om prestaties inzichtelijk, overzichtelijk en meetbaar te maken.

(financieel) gewaardeerd kunnen worden.

Uitgangspunt van dit project is dat deze ontwikkeling gefaciliteerd kan worden door de ontwikkeling van een KPI-systematiek 'duurzame kringlooplandbouw', kortweg KPI-K-systematiek genoemd.

\section{Kader 1: Opdracht}

Het ministerie van LNV heeft aan een consortium van partijen (WUR, Louis Bolk Instituut en Boerenverstand) opdracht gegeven om een KPI-systematiek voor Kringlooplandbouw (kortweg KPI-K-systematiek) te ontwikkelen. Dit moet een robuuste set aan KPI's (Kritische Prestatie Indicatoren) zijn die het mogelijk maakt om de bedrijfsvoering van de boer te sturen richting realisatie van bovengenoemde maatschappelijke opgaven, bijvoorbeeld via gestapelde waarderingen beloningsystemen. Vanwege het belang voor de landbouw is voldoende draagvlak in de boerenpraktijk en bij de betrokken ketenpartijen essentieel. Er zijn gebiedspilots voorzien in een aantal experimenteergebieden.

Een KPI-K-systematiek ambieert om prestaties van boerenbedrijven gekoppeld aan doelen van kringlooplandbouw op een eenduidige manier en in samenhang te meten. Het eenduidig meetbaar maken van prestaties op het boerenbedrijf kan helpen om boeren meer richting te geven in hoe zij kunnen bijdragen aan het realiseren van de doelen. Vervolgens ontstaat ook de mogelijkheid voor andere partijen (bijvoorbeeld overheden, afnemers, financiers, TBO's) om die betere prestaties te waarderen. Ten slotte biedt het ook verschillende gebruikers mogelijkheden om prestaties van individuele bedrijven op te tellen op hogere aggregatieniveaus (bijvoorbeeld nationaal, gebieden, ketens, sectoren). 


\section{$1.3 \mathrm{KPI}$ als bruikbaar instrument voor integrale sturing op het boerenerf}

Het vorige hoofdstuk zet uiteen dat er behoefte is aan een integrale aanpak voor sturing op langetermijnduurzaamheidsdoelen waarbij prestaties inzichtelijk en meetbaar worden gemaakt. Het werken naar duurzame doelen voor de landbouw kan gezien worden als een continu verbeterproces, of, zoals in het Deltaplan Biodiversiteitsherstel wordt gezegd: doen, leren, beter doen. Een dergelijk verbeterproces kan goed gevat worden in een plan-do-check-actcyclus, zie figuur 1 . Hierin worden in de planfase concrete doelen gesteld, in de do-fase maatregelen en activiteiten gerealiseerd, in de checkfase wordt gekeken in hoeverre de maatregelen bijdragen aan het doel en in de actfase wordt vervolgens bijgestuurd.

Kritische Prestatie Indicatoren (KPI's) spelen in een PDCA-cyclus een belangrijke rol, ze zijn cruciaal in de checkfase. KPI's zijn indicatoren voor prestaties die de voortgang op duurzaamheidsdoelen inzichtelijk maken en worden beïnvloed door specifieke maatregelen of acties op een specifiek schaalniveau voor een specifieke doelgroep (boeren). Daarbij ligt de focus op de prestaties waar de boer zelf invloed op heeft. Op deze manier vormen KPI's de verbinding tussen duurzaamheidsdoelen enerzijds en het handelingsperspectief van boeren anderzijds. Dit biedt meer garantie op succes, omdat het de boer de mogelijkheid biedt maatregelen te kiezen die het meest effectief, passend en lonend zijn in de eigen context en daarmee meer eigenaarschap geven op doelrealisatie. Het is dan wel belangrijk dat kennis beschikbaar is van de effectiviteit van maatregelen om bij te dragen aan de verschillende KPI's.

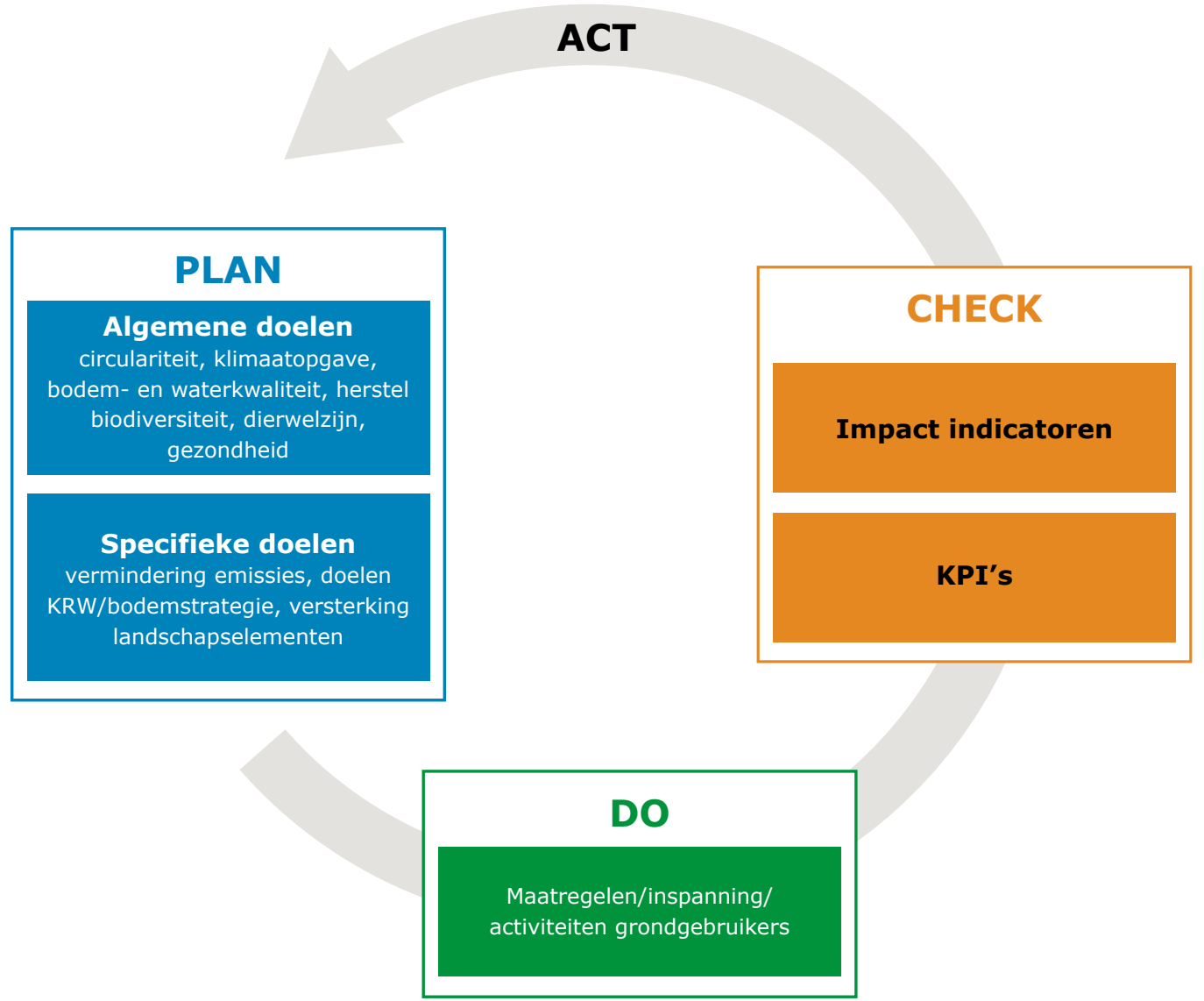

Figuur 1 Plan-do-check-act (PDCA)-cyclus voor doelen landbouw 
Uiteindelijk moet het sturen op prestaties bijdragen aan verbetering van klimaat, biodiversiteit, water-, lucht- en bodemkwaliteit en dus zichtbaar zijn in metingen van bijvoorbeeld de samenstelling van het slootwater, concentraties van ongewenste stoffen in de lucht of het aantal weidevogels. Echter, deze gewenste verbetering wordt mede bepaald door factoren waar een grondgebruiker zelf geen grip op heeft. Denk aan predatoren, klimaatverandering, emissies van andere bronnen of exoten waar andere maatregelen voor nodig zijn. Het gaat bij KPI's dus niet om indicatoren die de Door KPI's te gebruiken kunnen boeren zelf bepalen welke maatregelen zij inzetten om bij te dragen aan doelen. beoogde impact meten (bijvoorbeeld het aantal weidevogels), maar om de condities die het directe resultaat zijn van het handelen van de boer en tegelijkertijd cruciaal zijn voor de beoogde impact, zoals het areaal kruidenrijk grasland voor de weidevogels of de hoeveelheid broeikasgasemissies voor het tegengaan van klimaatverandering.

Door KPI's te gebruiken kunnen boeren zelf bepalen welke maatregelen zij inzetten om bij te dragen aan doelen. Daarmee is er vrijheid om doelen op eigen wijze, met vakmanschap in de vorm van kennis en kunde en binnen eigen omstandigheden te realiseren.

\section{Kader 2: Voortbouwen op dat wat er al is}

Uitgangspunt in dit project is om voort te bouwen op de bestaande kennis en initiatieven met betrekking tot gebruik van KPI's in de landbouw. Vanuit verschillende geledingen wordt gewerkt aan de ontwikkeling van KPI's op het gebied van duurzame bedrijfsvoering in de landbouw. In de meeste gevallen gebeurt dit voor specifieke doelen (bijvoorbeeld biodiversiteit), voor specifieke sectoren (bijvoorbeeld melkveehouderij of akkerbouw) of voor specifieke regio's (bijvoorbeeld provincie of regio). In deze projecten wordt veel kennis en ervaring opgedaan met het werken met KPI's voor de landbouw. Het voortbouwen op dat wat er al is en loopt is cruciaal voor de verdere ontwikkeling van een KPI-K-systematiek. Een eerste opzet voor KPI's voor kringlooplandbouw is beschreven in Erisman en Verhoeven (2020). Het gaat bij nieuwe initiatieven om zowel de inhoudelijke kennis als de ervaringen met bijvoorbeeld het proces om te komen tot een KPI-systematiek in interactie met betrokkenen.

De initiatieven waarbij voornamelijk de aansluiting gezocht wordt zijn:

- Biodiversiteitsmonitor melkveehouderij: Planet Proof

- Biodiversiteitsmonitor akkerbouw versie 0.2

- Brabantse Biodiversiteitsmonitor Melkveehouderij

- Duurzame melkveehouderij Drenthe

- IBP Zuidwestelijke Delta

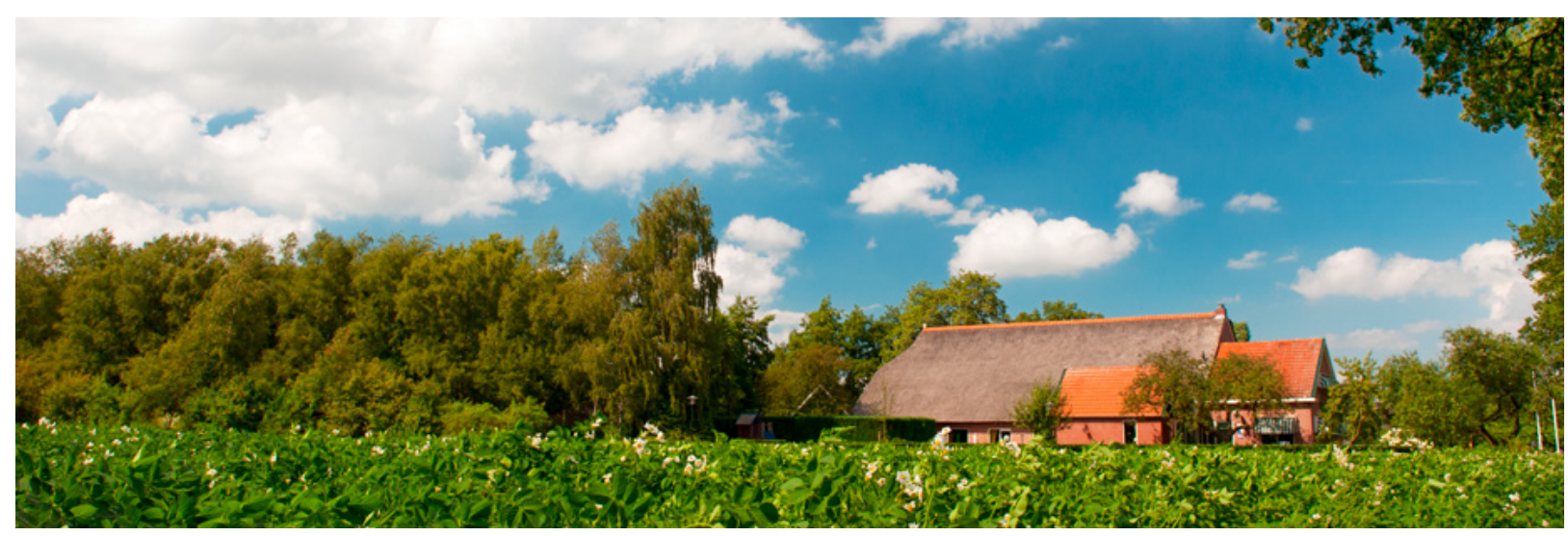




\title{
2 Afbakening KPI-systematiek
}

Voor de verdere ontwikkeling van een KPI-systematiek is het belangrijk om een heldere afbakening als vertrekpunt te hanteren. De KPI-K-systematiek kan alleen werken als het duidelijk is waar deze wel en geen betrekking op heeft. In dit hoofdstuk wordt deze afbakening verder uitgewerkt in de vorm van een conceptueel kader (wat is de beoogde werking van de KPI-systematiek) en systeemeisen (wat moet de KPI-systematiek kunnen?).

\author{
De KPI-K-systematiek kan alleen werken \\ als het duidelijk is waar deze wel en \\ geen betrekking op heeft.
}

\subsection{Conceptueel kader}

Figuur 2 vat de beoogde werking van een dergelijke systematiek schematisch samen. De bovenkant van de figuur geeft de doelen voor duurzame kringlooplandbouw weer (vanuit onder andere de Kringlooplandbouwvisie). Om deze doelen concreter te maken voor een KPI-systematiek zijn ze uitgewerkt tot specifiekere doelen. Met deze specifiekere doelen kan een goede verbinding worden gemaakt naar de gewenste bedrijfsvoering. Dit wil overigens niet zeggen dat er voor elk specifiek doel een aparte KPI moet komen. Het gaat uiteindelijk om een integrale KPI-set die gezamenlijk de doelen moet bedienen.

Onderaan de figuur staan de maatregelen die boeren kunnen toepassen op hun bedrijf. Doelen en maatregelen ontmoeten elkaar in het midden: bij de KPI's, die tezamen de integrale KPI-set vormen. KPI's kunnen samengesteld worden uit indicatoren die boeren al gebruiken voor de bedrijfsvoering. Het geheel van doelen, KPI-set en mogelijke maatregelen vormt de KPI-systematiek.

Voor de afbakening van de beoogde werking van de systematiek worden de volgende uitgangspunten gehanteerd. De KPI-systematiek:

- gaat uit van de volgende algemene doelen: 1) verbeteren circulariteit; 2) omgaan met en tegengaan van klimaatverandering; 3) verbeteren waterkwaliteit en -beheer; 4) verbeteren bodemkwaliteit; 5) herstellen biodiversiteit; 6) verbeteren plant- en diergezondheid; 7) verbeteren sociaaleconomische positie van de boer. Voor sommige doelen zijn (inter)nationale verplichtingen afgesproken die leidend zullen zijn. Op de eerste zes doelen wordt een set aan KPI's geformuleerd. Het zevende doel (versterken sociaaleconomische positie) wordt nagestreefd doordat de KPI-systematiek het mogelijk maakt om betere prestaties op het gebied van de andere zes doelen (financieel) te belonen.

- brengt de prestaties in beeld van individuele ondernemers in de agrarische sector op bedrijfsniveau. Het betreft de prestaties waar boeren zelf invloed op hebben en die per bedrijf vastgesteld kunnen worden, maar wel op te tellen zijn tot verschillende schaalniveaus waarop de doelen betrekking hebben.

- heeft betrekking op de productieomgeving van het landbouwbedrijf: de natuurlijke omgeving waar het bedrijf zich in bevindt met de ecologische condities die daarbij horen, staan centraal. De KPI's hebben daarom zo veel mogelijk betrekking op de specifieke condities van het bedrijf in zijn directe omgeving. Wel dient afwenteling van negatieve effecten naar andere gebieden te worden voorkomen.

- is in principe bedoeld voor agrarische bedrijven van alle landbouwsectoren in Nederland.

- verbindt verschillende ruimtelijke schaalniveaus door prestaties op bedrijfsniveau te vertalen naar bijdragen aan doelen op hogere schaalniveaus en vice versa: doelen die op verschillende schaalniveaus (landen, regio's, sectoren, ketens) door te vertalen naar prestaties op bedrijfsniveau. 


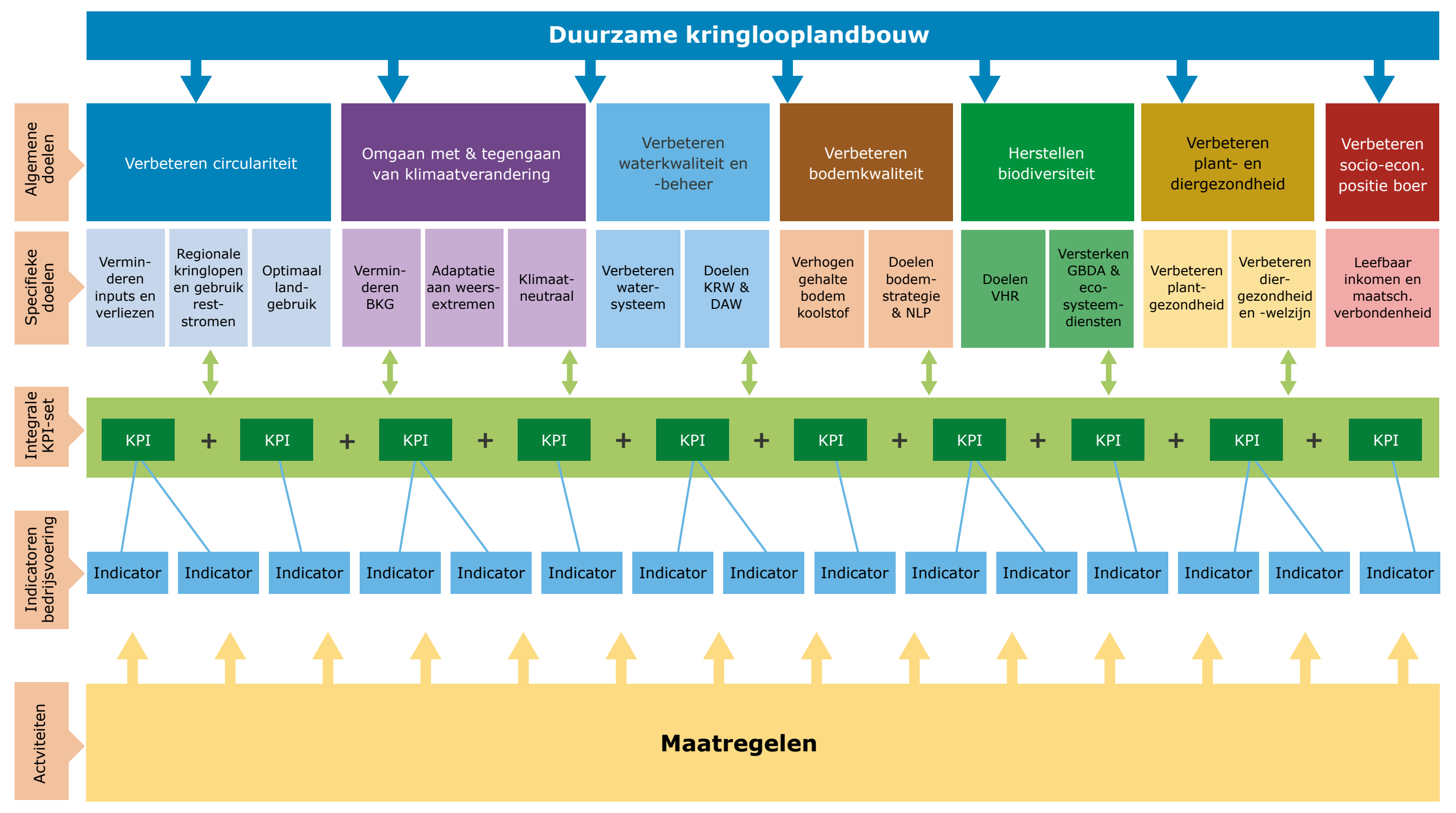

Figuur 2: Conceptueel kader KPI-K-systematiek: samenhang algemene en specifieke doelen, KPI's en maatregelen. $\mathrm{BKG}=$ broeikasgassen, $\mathrm{KRW}=$ kader richtlijn water, $\mathrm{DAW}=$ deltaplan agrarisch waterbeheer,

$\mathrm{NPL}=$ nationaal programma landbouwbodems, $\mathrm{VHR}=$ vogel- en habitatrichtlijn, GBDA = groenblauwe dooradering . 


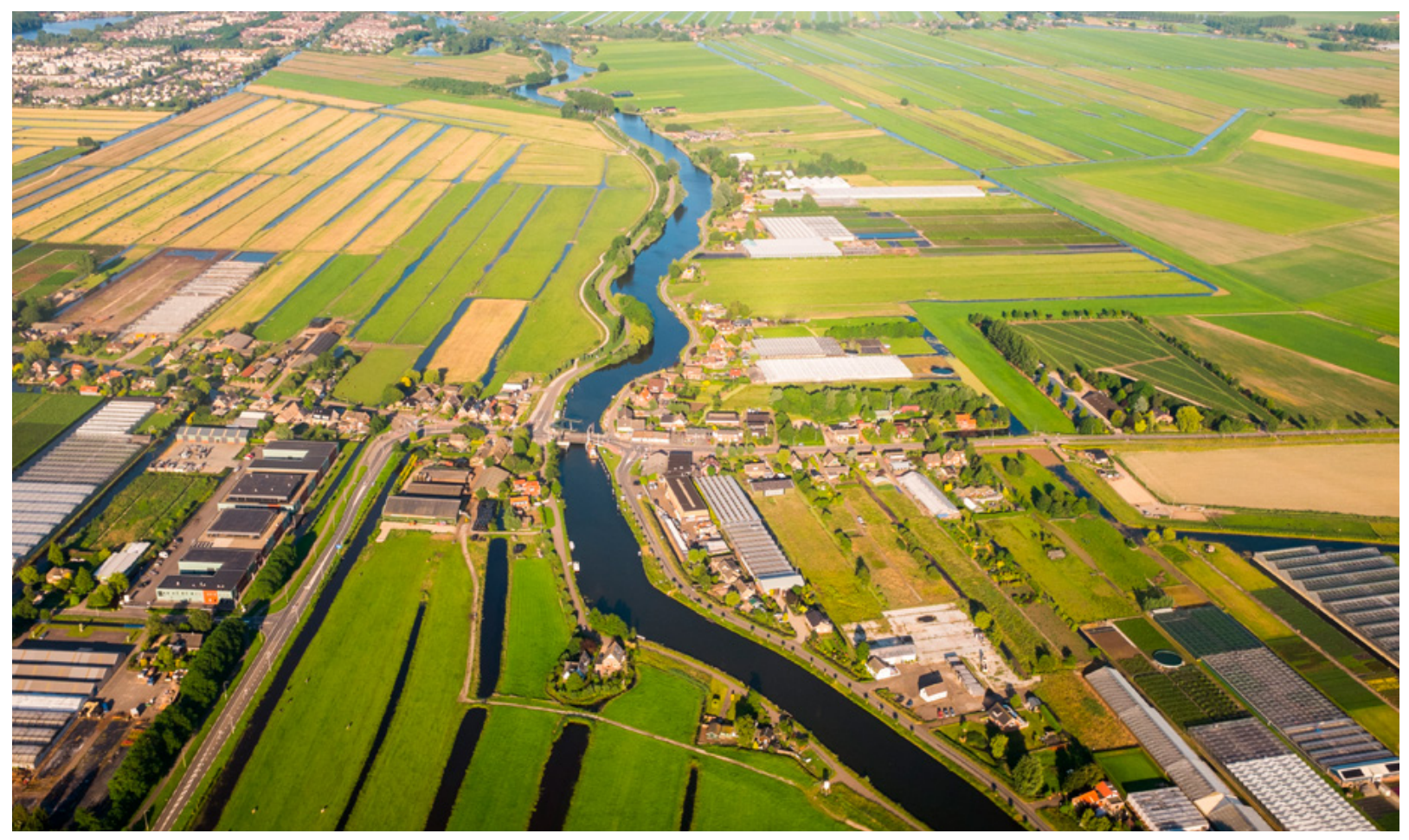

Tabel 1 geeft de definities van veelgebruikte termen weer.

\begin{tabular}{|c|c|}
\hline Term & Definitie \\
\hline Algemeen doel & $\begin{array}{l}\text { Doel dat richtinggevend is, maar niet rechtstreeks kan worden bereikt, omdat er te } \\
\text { veel factoren een rol spelen die men niet kent of niet beheerst. }\end{array}$ \\
\hline Specifiek doel & $\begin{array}{l}\text { Een doel dat een bijdrage levert aan het bereiken van het algemene doel en } \\
\text { concreter is, bijvoorbeeld volledig klimaatneutrale bedrijfsvoering. }\end{array}$ \\
\hline Prestatie & $\begin{array}{l}\text { Bijdrage van individuele boer aan specifiek doel, zo veel mogelijk uitgedrukt in } \\
\text { kwantitatieve indicatoren die objectieve vergelijking met doelen / prestaties (of } \\
\text { drempel- en streefwaarden) mogelijk maakt. }\end{array}$ \\
\hline KPI & $\begin{array}{l}\text { Kritische Prestatie Indicator. Een indicator die gebruikt wordt om de prestatie van } \\
\text { een bedrijf ten opzichte van specifieke doelen te meten. Een KPI kan gezien } \\
\text { worden als een indicator die de resultaten meet van maatregelen die ondernomen } \\
\text { worden op een bedrijf en in hoeverre deze bijdragen aan de beoogde doelen, maar } \\
\text { geven daarbij geen voorschriften voor hoe de doelen te behalen. }\end{array}$ \\
\hline KPI-set & $\begin{array}{l}\text { Een aantal samenhangende KPI's die integraal sturen richting meerdere doelen. } \\
\text { Deze set van KPI's moet dan ook altijd in zijn geheel toegepast worden, waarmee } \\
\text { inzicht gekregen kan worden in hoe een boer/bedrijf presteert ten opzichte van } \\
\text { maatschappelijke opgaven, zoals het herstel van biodiversiteit, bodemkwaliteit, } \\
\text { landschap, klimaat en milieu (Erisman \& Verhoeven, 2020). }\end{array}$ \\
\hline KPI-systematiek & $\begin{array}{l}\text { Het geheel van doelen, set van KPI's, bijbehorende streefwaarden en handelings- } \\
\text { perspectief voor betrokken partijen en de logische samenhang daartussen. Een } \\
\text { KPI-systematiek kan worden gezien als een werkend geheel dat het mogelijk } \\
\text { maakt om de prestaties van onderliggende eenheden (in dit geval het landbouwbe- } \\
\text { drijf) te meten met als doel ze te sturen in de richting van doelen op een hoger } \\
\text { aggregatieniveau (in dit geval de doelen van de kringlooplandbouw). }\end{array}$ \\
\hline Maatregelen & Een actie die een boer uitvoert op zijn bedrijf / bedrijfsareaal. \\
\hline Streefwaarde & De waarde van een KPI die nodig is om een prestatie te halen. \\
\hline Indicator & $\begin{array}{l}\text { Een kengetal dat een signalerende functie heeft en gebruikt kan worden om } \\
\text { processen te volgen. }\end{array}$ \\
\hline
\end{tabular}

Tabel 1 Definities van veelgebruikte termen 


\subsection{Systeemeisen}

Systeemeisen kunnen worden gezien als een nadere detaillering van de hierboven beschreven beoogde werking van de KPI-systematiek. De systeemeisen zullen worden gebruikt om richting te geven aan de verdere ontwikkeling van de systematiek en als toetsingskader in het vervolg van het project.

Inhoudelijk moet de KPI-K-systematiek:

- Inzicht bieden in de, voor het realiseren van de doelen van kringlooplandbouw, relevante prestaties van individuele boerenbedrijven. Met prestaties wordt datgene bedoeld dat binnen het bereik van de boer ligt om te beïnvloeden, uitgedrukt in kwantitatieve indicatoren die objectieve vergelijking met doelen / prestaties mogelijk maken. Hierdoor wordt het mogelijk om prestaties op bedrijfsniveau te relateren aan doelen op hogere aggregatieniveaus (nationaal of regionaal), bijvoorbeeld via streefwaarden. Het gaat derhalve om een meetbare bijdrage (indicatoren) aan de specifieke doelen.

- Effectief zijn. De KPI's moeten een duidelijke en aantoonbare relatie hebben met de beoogde doelen en maatregelen. Dit wil zeggen dat de effecten van de belangrijkste maatregelen die boeren kunnen toepassen om de prestaties te leveren (handelingsperspectief) tot uiting komen in de opgenomen KPI's. En dat verbetering op de KPI bijdraagt aan het halen van de doelen. Op die manier functioneren KPI's als een verbindende schakel tussen maatregelen en de beoogde impact. KPI's moeten op korte termijn beïnvloedbaar zijn door het nemen van maatregelen.

- Integraal sturen richting realisatie van de specifieke doelen van kringlooplandbouw. Dit wil zeggen dat het effect van de samenhangende set van KPI's vooruitgang op alle specifieke doelen moet realiseren. Er mag geen sprake van zijn dat voortgang op een deel van de doelen wordt afgewenteld op de realisatie van andere doelen. Het uitgangspunt hierbij is dat KPI's worden geselecteerd waarbij sturing in de gewenste richting positief bijdraagt aan meerdere doelen. Het aantal KPI's blijft idealiter beperkt, omwille van de eenvoud en transparantie van het systeem maar is wel zo breed dat het geheel aan doelen gedekt worden ('zo min als mogelijk, zo veel als nodig is om alle doelen af te dekken').

- Ruimte bieden voor het vakmanschap van de boer om eigen invulling te kiezen naar het gestelde doel zodat ondernemers een zo groot mogelijke speelruimte hebben om de maatregelen te selecteren die passen bij de bedrijfssituatie en bijdragen aan de gestelde doelen of KPI's. KPI's worden zodanig gekozen en gedefinieerd dat het objectieve vergelijking van verschillende typen bedrijven op de duurzaamheidsprestaties mogelijk maakt. Effecten van zowel technische maatregelen (bijvoorbeeld het toepassen van emissiearme technieken of stallen) als aanpassingen in de bedrijfsvoering (bijvoorbeeld het verlagen van de kunstmestgift of het aanpassen van het rantsoen) komen tot uiting in de KPI's.

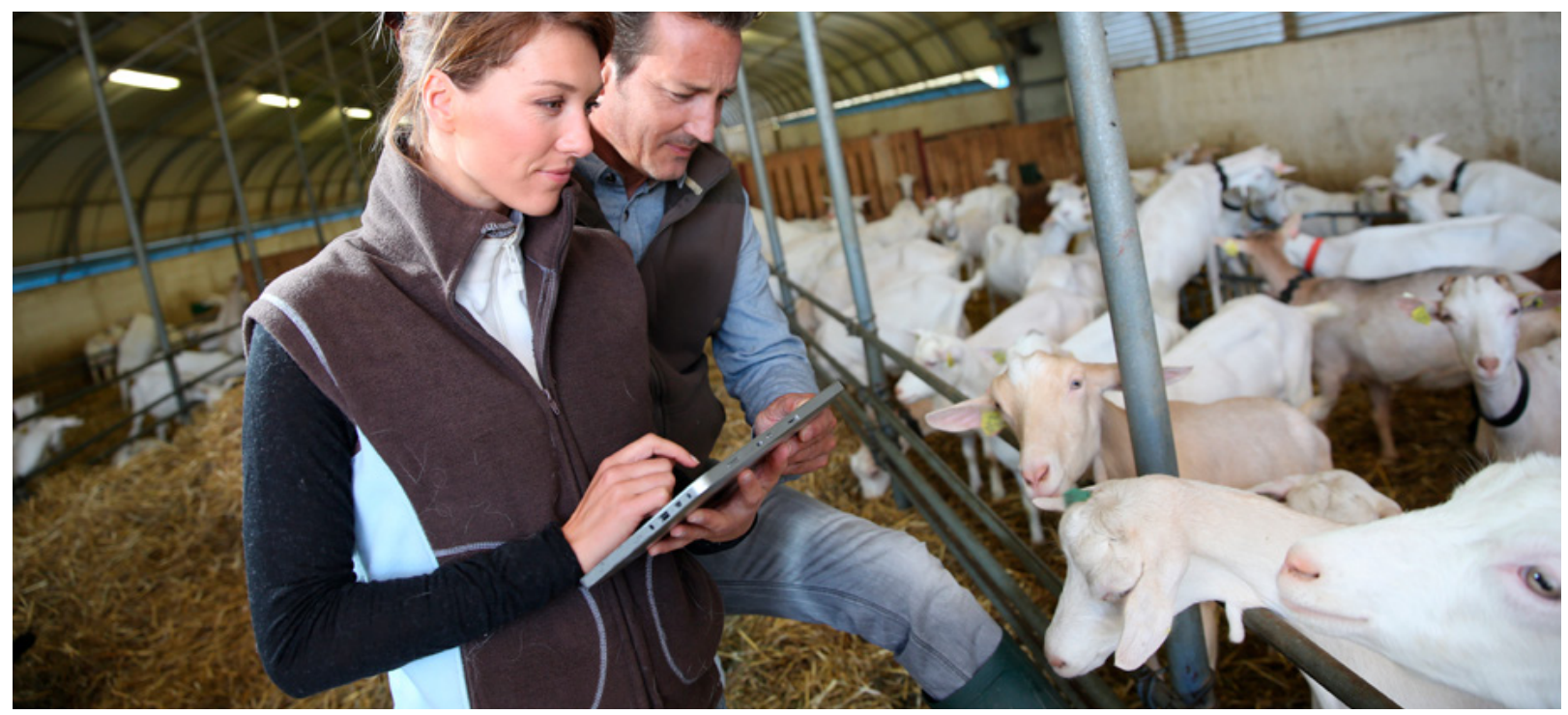


Randvoorwaardelijk moet de KPI-K-systematiek:

1 Aantrekkelijk zijn voor partijen om te gebruiken, transparant en uitlegbaar zijn. Omdat een groot gebruik wordt nagestreefd door een breed scala aan partijen is het belangrijk dat het systeem transparant, eenvoudig en aantrekkelijk is voor verschillende stakeholders (denk hierbij aan zowel boeren en adviseurs als marktpartijen, overheden en andere maatschappelijke stakeholders). Dit vereist dat het systeem logisch in elkaar steekt: redeneerlijnen, relaties en samenhang moeten expliciet worden gemaakt en zo eenvoudig mogelijk weergegeven. Omwille van deze transparantie is het belangrijk dat de systematiek zo eenvoudig mogelijk wordt gehouden.

2 Werkbaar zijn voor de hele Nederlandse landbouw. Dit wil zeggen dat de systematiek in principe werkbaar moet zijn voor alle landbouwbedrijven in Nederland. De ambitie is om ook over landbouwbedrijven heen conclusies te kunnen trekken over voortgang op het realiseren van de doelen van kringlooplandbouw. Resultaten moeten op gebiedsniveau op te tellen zijn. Dit resulteert in de eis dat onnodige verschillen in KPI's (zowel de totale set als de definitie van individuele KPI's) tussen sectoren zo veel mogelijk moeten worden vermeden. Als om inhoudelijke of praktische redenen toch verschillen in KPI's tussen sectoren nodig zijn, dan is een systematische benadering nodig die ervoor zorgt dat resultaten tussen sectoren toch vergelijkbaar worden en op te tellen zijn. Het voorkomen van onnodige verschillen tussen sectoren is ook van belang omdat 1 ) een deel van de oplossingen naar kringlooplandbouw zit op de raakvlakken tussen sectoren en 2) omdat er ook gemengde landbouwbedrijven zijn waarvoor het systeem werkbaar moet zijn.

3 Bruikbare resultaten bieden voor gebruikers. Ten eerste is het van belang dat het systeem de boer en zijn adviseur op een toegankelijke manier inzicht biedt in de voortgang op de benodigde duurzaamheidsprestaties. Daarnaast is het belangrijk dat potentiële eindgebruikers zoals afnemers en brancheorganisaties, regionale overheden (bijvoorbeeld rondom gebiedsprocessen of vergunningverlening) en landelijke overheden de resultaten kunnen gebruiken om betere prestaties te kunnen stimuleren (bijvoorbeeld door een financiële beloning). Het is belangrijk dat het systeem aansluit bij eisen die dit soort partijen hebben hieromtrent. Te denken valt bijvoorbeeld aan overzichtelijke rapportageformats, tijdige beschikbaarheid en het kunnen delen van de uitkomsten. Dit dient in de komende fase van het project nog verder te worden uitgewerkt.

4 Gekoppeld zijn aan bestaande datasets, dan wel aan data die binnen afzienbare termijn voor alle bedrijven beschikbaar kunnen komen. Tevens is het belangrijk om goede afspraken te maken over het eigenaarschap van deze systemen en bijbehorende data. Omdat volledige dekking van alle doelen ook een vereiste is, kan het zijn dat er ontwikkeltrajecten moeten worden gestart om de benodigde datasystemen te organiseren.

5 Administratieve lasten en kosten beperken. Dit wil zeggen dat de administratieve lasten en kosten van het systeem voor de landbouwbedrijven zo beperkt mogelijk moeten worden gehouden. Dit kan worden gerealiseerd door zo veel mogelijk aan te sluiten bij bestaande administratie en reeds ontwikkelde datasystemen waarin kengetallen over duurzame bedrijfsvoering worden berekend. KPI's moeten snel, goedkoop en betrouwbaar te meten zijn en/of snel en betrouwbaar uit bestaande registratie- en monitorsystemen onttrokken kunnen worden met minimale administratieve lasten.

6 Robuust en fraudebestendig zijn. Dit betekent dat de mogelijkheden om resultaten te manipuleren beperkt zijn. Bij voorkeur worden mechanismen ingebouwd die ervoor zorgen dat manipulatie van resultaten niet lonend is. Een belangrijke voorwaarde is dat onderliggende informatie- en datasystemen die gebruikt worden om de KPI's te berekenen, te controleren en te handhaven zijn en de juridische toets kunnen doorstaan. 


\section{Mogelijke toepassing en vervolgstappen}

\subsection{Verwachte toepassing van de KPI-systematiek}

Wanneer een goede KPI-K-systematiek is ontwikkeld, kan die vervolgens op verschillende manieren worden gebruikt. Primair als dashboard voor boeren: een KPI-K-systematiek biedt de boer dan zelf inzicht in de voortgang van de eigen prestaties op het gebied van de doelen. Maar ook om prestaties te waarderen en te belonen. Hierbij kunnen verschillende partijen, zoals afnemers, overheden (regionaal en landelijk), TBO's en financiers de systematiek gebruiken om te sturen naar betere prestaties, bijvoorbeeld door het organiseren van financiële stimulansen, ontheffing van vergunningsvoorwaarden, meer planologische ruimte of als alternatief voor maatregelvoorschriften. Om dit te kunnen doen is het aannemelijk dat gebruikers drempel-, en streefwaarden van de KPI's gaan hanteren die gehaald moeten worden om voor een bepaalde beloning in aanmerking te komen. Het benoemen van dit soort waarden vereist een gedegen analyse en kan niet zonder beleidsmatige afwegingen. Afstemming tussen partijen is essentieel.

Zoals eerder aangegeven omvat een KPI-systematiek meerdere doelen, landbouwsectoren en ruimtelijke schaalniveaus: van landelijk tot bedrijfsniveau. Het ultieme doel is om een generiek toepasbare set van KPI's op te stellen die in alle gebieden en door alle bedrijven kan worden toegepast. Hoe eenduidiger de set KPI's, hoe makkelijker het wordt om resultaten met elkaar in verbinding te brengen, hoe groter het aantal partijen waarvoor de systematiek aantrekkelijk wordt om te gebruiken en hoe efficiënter operationalisering en kwaliteitsborging kunnen worden georganiseerd.

Toch zal er in een aantal gevallen behoefte zijn om KPI's naar sectoren of regio's te verbijzonderen. Tussen sectoren zijn er verschillen in termen van doelen, bijvoorbeeld diergezondheid en -welzijn speelt niet voor de akkerbouw, en in de niet-grondgebonden veehouderij zijn doelen met betrekking tot de bodem minder relevant. Ook speelt databeschikbaarheid een rol. Niet alle KPI's kunnen voor iedere sector worden berekend. Dit kan een tijdelijk probleem zijn. Per sector zal worden nagegaan welke verbijzondering in KPI's nodig is om de voor de sector specifieke opgaven te bedienen. Dit zou kunnen zijn in de vorm van extra KPI's voor individuele sectoren, maar mogelijk kan ook worden gedacht aan KPI's die per sector een andere invulling hebben. Aangegeven dient te worden of en hoe sectorspecifieke KPI's op termijn geüniformeerd kunnen worden. Tussen regio's bestaan er verschillen in bijvoorbeeld landschapsstructuur en grondsoort die invloed hebben op de score op KPI's. Er moet daarom ruimte zijn voor een regiospecifieke invulling. Dit zou in theorie kunnen door middel van het toevoegen van regiospecifieke KPI's, maar ook door bij de invulling van KPI's onderscheid te maken naar regio's. Bijvoorbeeld voor een KPI met betrekking tot aandeel natuur- en landschapsbeheer: bij de invulling van deze KPI

\section{Een KPI-K-systematiek biedt de boer zelf inzicht in de voortgang van de eigen prestaties} kunnen bijvoorbeeld regionale randvoorwaarden worden gesteld door type beheer landschapspecifiek te specificeren. Gezien het belang van een uniforme set, is het uitgangspunt vooralsnog dat vooral mogelijkheden voor regionale invulling van KPI's zal worden verkend.

\section{Optimalisatie op gebiedsniveau door samenwerking}

Voor kringlooplandbouw is het sluiten van nutriëntenkringlopen zeer belangrijk, zodat geen emissies naar het milieu plaatsvinden. In de landbouwsector geeft dat met name kansen door samenwerking tussen plantaardige productie en dierlijke productie. Het opnemen van reststromen van de ene sector of bedrijf als input voor de andere, stimuleert kringlopen en moet beloond worden. In principe is het uitgangspunt van de KPI-systematiek dat het betrekking heeft op individuele bedrijven. Toch biedt het duidelijk meerwaarde om bij het opstellen van de KPI-systematiek wel rekening te houden met dit soort samenwerkingsverbanden. Dit kan gedaan worden door ook KPI's op te nemen die samenwerking tussen sectoren (voor zover deze bijdraagt aan het realiseren van de doelen) te stimuleren. 


\subsection{Toetsing van eerste kernset in gebiedspilots}

Om te komen tot een KPI-K-systematiek zijn gebiedspilots voorzien in een aantal gebieden. Samen met initiatieven waarin met KPI's wordt gewerkt, met gebiedspartijen en onderzoekers wordt er in 2021 gewerkt aan een KPI-systematiek. Hierin zijn twee cycli voorzien: de eerste 'lus' in mei/juni en de tweede 'lus' in september/oktober. Beide hebben in deze fase het karakter van 'droogzwemmen' met de KPI-Ksystematiek. De eerste cyclus zal met name gericht zijn op de betrokkenen uit het gebied; in de tweede cyclus wordt deze groep aangevuld met bijvoorbeeld betrokken ketenpartijen (voedselindustrie, banken, ngo's). Een eerste voorstel voor een KPI-K-systematiek vormt daarbij het uitgangspunt. Zoals aangegeven wordt hierbij voortgebouwd op de diverse lopende initiatieven die werken met een KPI-systematiek. Om een eerste indruk te geven welke KPI's kansrijk zijn om onderdeel te kunnen worden van een KPI-Ksystematiek geeft tabel 2 een overzicht van mogelijke KPI's. Vermeld staat aan welk specifiek doel ze gerelateerd zijn, hoe ze te meten zijn en op welke sector ze van toepassing zijn. Naast bestaande KPI's Iopen er diverse trajecten die mogelijk interessante KPI's opleveren. Denk aan de OpenBodemIndex, maar ook aan een KPI die het bouwplan beoordeelt vanuit de gecombineerde opgave of een KPI over samenwerking akkerbouw-veehouderij. Ook zijn er ontwikkelingen met satellietbeelden, enz. Vanzelfsprekend worden die meegenomen in de zoektocht.

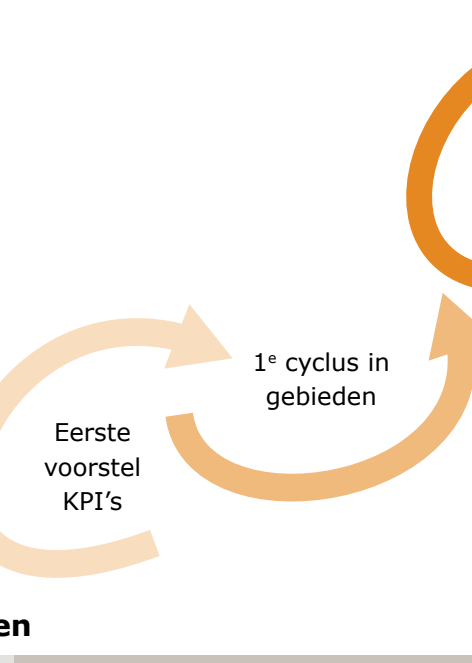

bestaande initiatieven

2020

\section{Eindbeeld}

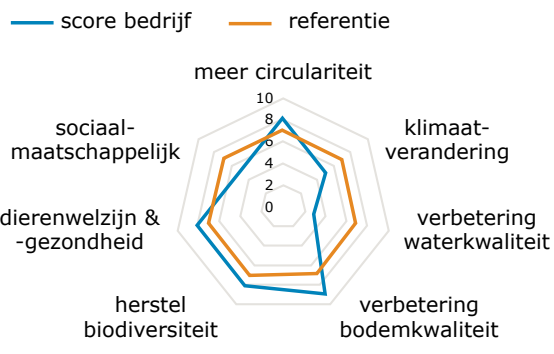

Regionale KPI's

Figuur 3 Schematische weergave van het proces van ontwikkeling KPI-K-systematiek.

\subsection{Leer- en ontwikkelvragen}

De gebiedsgesprekken zullen vooral gaan over de verdere ontwikkeling van de KPI-K-systematiek. De volgende vragen zullen aan de orde komen:

1 Hoe wordt aangekeken tegen het conceptuele kader: de samenhang tussen algemene en specifieke doelen, KPI's en maatregelen? Is dat duidelijk, missen er essentiële zaken? Moeten er zaken worden aangescherpt? Wat zijn argumenten daarvoor?

2 Hoe wordt aangekeken tegen de afbakening van de doelen? Missen er essentiële zaken? Staan er overbodige of overlappende doelen tussen? Zijn de specifieke doelen concreet genoeg om de juiste set aan KPI's te benoemen?

3 Hoe wordt aangekeken tegen de eerste kernset van KPI's? Welke definitiekwesties spelen er? Welke datakwesties zijn te voorzien? Is de set volledig? Is de set werkbaar? Waarom wel of niet? Zijn er slimmere KPI's denkbaar die hetzelfde doen (of meer)? 


\begin{tabular}{|c|c|c|c|c|c|c|c|}
\hline \multirow[t]{2}{*}{ KPI } & \multirow[t]{2}{*}{ Doel } & \multirow{2}{*}{$\begin{array}{l}\text { Omschrijving / } \\
\text { hoe te meten? }\end{array}$} & \multicolumn{5}{|c|}{ Sector } \\
\hline & & & Melk & Intv & Akk & Volle & Kas \\
\hline Stikstof efficiëntie & Verbeteren circulariteit & $\begin{array}{l}\text { Totale afvoer van } \mathrm{N} \text { met } \\
\text { afstandscriterium gedeeld } \\
\text { door externe inputs } \\
\text { (krachtvoer/kunstmest) }\end{array}$ & $X$ & $x$ & $x$ & $\mathrm{X}$ & $x$ \\
\hline Ammoniakuitstoot & Verminderen emissies & $\begin{array}{l}\text { Ammoniakemissie als totale } \\
\text { emissie van ammoniak }\left(\mathrm{NH}_{3}\right) \\
\text { per hectare }(\mathrm{kg} \mathrm{NH} / \mathrm{ha})\end{array}$ & $X$ & $\mathrm{X}$ & - & - & - \\
\hline Fosfaat overschot & $\begin{array}{l}\text { Verminderen emissies } \\
\text { Herstellen biodiversiteit }\end{array}$ & Aanvoer $\mathrm{P}$ - afvoer $\mathrm{P}$ & $\mathrm{X}$ & $\mathrm{X}$ & - & - & - \\
\hline $\begin{array}{l}\text { Aandeel voedsel } \\
\text { gewassen in } \\
\text { bouwplan }\end{array}$ & Verbeteren circulariteit & $\begin{array}{l}\text { \% voedselgewassen in } \\
\text { bouwplan per kalenderjaar }\end{array}$ & $X$ & - & $X$ & $\mathrm{X}$ & $\mathrm{X}$ \\
\hline $\begin{array}{l}\text { Broeikasgasemissie/ } \\
\text { Carbon Footprint }\end{array}$ & $\begin{array}{l}\text { Verminderen } \\
\text { broeikasgassen }\end{array}$ & $\begin{array}{l}\text { Uitstoot } \mathrm{CO}_{2} \text { equivalenten/ } \\
\text { ha (via Kringloopwijzer of } \\
\text { CoolFarmtool) }\end{array}$ & $\mathrm{X}$ & $\mathrm{X}$ & $\mathrm{X}$ & $\mathrm{X}$ & $\mathrm{x}$ \\
\hline $\begin{array}{l}\text { Milieubelasting } \\
\text { gewasbeschermings } \\
\text { middelen }\end{array}$ & $\begin{array}{l}\text { Vermindering emissies } \\
\text { Verbeteren } \\
\text { waterkwaliteit } \\
\text { Herstellen biodiversiteit }\end{array}$ & $\begin{array}{l}\text { Milieubelastingspunten/ } \\
\text { aandeel glycofosfaat (via } \\
\text { CoolFarmtool) }\end{array}$ & $\mathrm{X}$ & $X$ & $x$ & $x$ & $X$ \\
\hline $\begin{array}{l}\text { Organische stof } \\
\text { balans }\end{array}$ & $\begin{array}{l}\text { Verbeteren } \\
\text { bodemkwaliteit }\end{array}$ & $\begin{array}{l}\text { Aanvoer van organische stof } \\
\text { (incl. gewasresten) minus } \\
\text { afbraak }\end{array}$ & $x$ & - & $\mathrm{X}$ & $\mathrm{X}$ & - \\
\hline $\begin{array}{l}\text { Gewasdiversiteit } \\
\text { (kruidenrijk } \\
\text { grasland) }\end{array}$ & Herstellen biodiversiteit & $\begin{array}{l}\text { Index gewasdiversiteit/ } \\
\% \text { kruidenrijk grasland } \\
\text { vastgelegd in contracten - } \\
\text { geregistreerd }\end{array}$ & $\mathrm{X}$ & - & $X$ & $x$ & - \\
\hline $\begin{array}{l}\text { Aandeel } \\
\text { gereduceerde } \\
\text { grondbewerking } \\
\text { (incl blijvend } \\
\text { grasland) }\end{array}$ & $\begin{array}{l}\text { Verbeteren } \\
\text { bodemkwaliteit }\end{array}$ & $\begin{array}{l}\% \text { grond met NKG of met } \\
\text { andere vorm van } \\
\text { gereduceerde grond } \\
\text { bewerking/\% blijvend } \\
\text { grasland van de totale } \\
\text { bedrijfsoppervlakte }\end{array}$ & $\mathrm{X}$ & - & $x$ & $x$ & - \\
\hline $\begin{array}{l}\text { Aandeel natuur- en } \\
\text { landschapsbeheer }\end{array}$ & Herstellen biodiversiteit & $\begin{array}{l}\% \text { agrarisch natuurbeheer } \\
\text { vastgelegd in contracten }\end{array}$ & $X$ & $X$ & $x$ & $x$ & $\mathrm{X}$ \\
\hline $\begin{array}{l}\text { Aandeel } \\
\text { groenblauwe } \\
\text { dooradering }\end{array}$ & Herstellen biodiversiteit & $\%$ groen-blauwe dooradering & $\mathrm{X}$ & $X$ & $\mathrm{X}$ & $\mathrm{X}$ & $X$ \\
\hline $\begin{array}{l}\text { Weidegang/ } \\
\text { vrije uitloop }\end{array}$ & Dierenwelzijn & $\begin{array}{l}\text { Aantal dagen per jaar } \\
\text { weidegang }\end{array}$ & $x$ & $\mathrm{X}$ & - & - & - \\
\hline $\begin{array}{l}\text { Beter leven } \\
\text { Sterrensysteem }\end{array}$ & Dierenwelzijn & $\begin{array}{l}\text { Volgens sterrensysteem } \\
\text { dierenbescherming }\end{array}$ & $X$ & $X$ & - & - & - \\
\hline
\end{tabular}

Tabel 2 Overzicht van mogelijke KPI's voor KPI-K-systematiek. 


\section{Colofon}

\section{Auteurs}

Anne van Doorn ${ }^{1}$, Joan Reijs ${ }^{1}$, Jan Willem Erisman4 Frank Verhoeven³, Daan Verstand1, Wouter de Jong5,

Karin Andeweg ${ }^{1}$, Nick van Eekeren ${ }^{2}$, Anne Charlotte Hoes ${ }^{1}$, Heleen van Kernebeek ${ }^{1}$, Chris Koopmans ${ }^{2}$, Jan Paul Wagenaar ${ }^{2}$ en Pieter de Wolf ${ }^{1}$

Photocredits: Shutterstock

DOI 10.18174/548327, https://doi.org/10.18174/548327

\section{(c) (1) ()}

Dit werk valt onder een Creative Commons

Naamsvermelding-Gelijk Delen 4.0

Internationaal-licentie

\section{Contact \& information}

Anne van Doorn

Wageningen Environmental Research

Postbus 47

6700 AA Wageningen

anne.vandoorn@wur.nl

www.wur.nl
De missie van Wageningen University \& Research is 'To explore the potential of nature to improve the quality of life'. Binnen Wageningen University \& Research bundelen Wageningen University en gespecialiseerde onderzoeksinstituten van Stichting Wageningen Research hun krachten om bij te dragen aan de oplossing van belangrijke vragen in het domein van gezonde voeding en leefomgeving. Met ongeveer 30 vestigingen, 6.800 medewerkers ( $6.000 \mathrm{fte}$ ) en 12.900 studenten behoort Wageningen University \& Research wereldwijd tot de aansprekende kennisinstellingen binnen haar domein. De integrale benadering van de vraagstukken en de samenwerking tussen verschillende disciplines vormen het hart van de unieke Wageningen aanpak. 